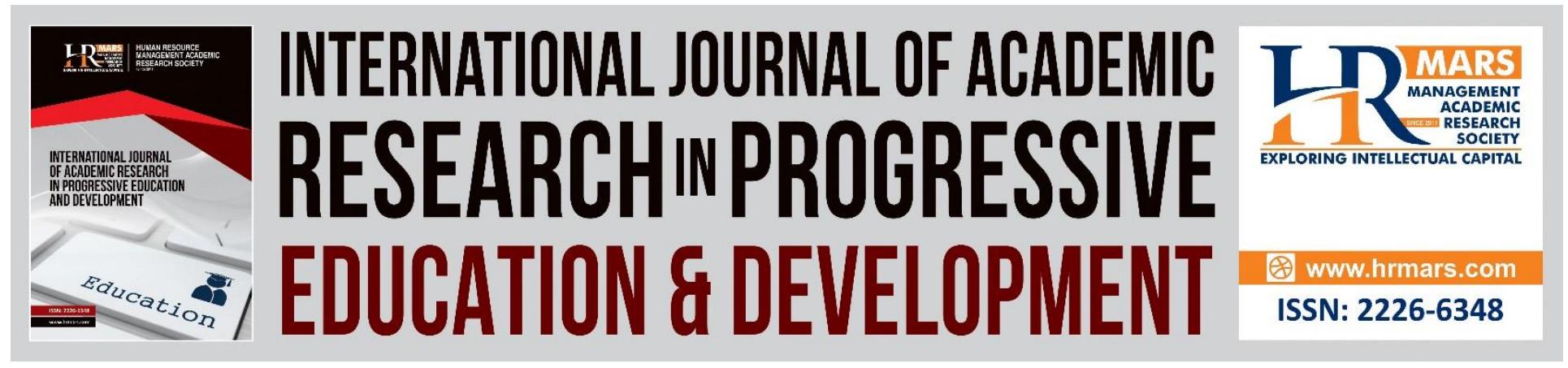

\title{
The Influence of Distributed Leadership on Teachers' Competency in Secondary School
}

Hairul Azman Mohd Hata, Mohamed Yusoff Mohd Nor, Aida Hanim A. Hamid

To Link this Article: http://dx.doi.org/10.6007/IJARPED/v9-i4/8127

DOI:10.6007/IJARPED/v9-i4/8127

Received: 10 October 2020, Revised: 08 November 2020, Accepted: 19 December 2020

Published Online: 30 December 2020

In-Text Citation: (Hata et al., 2020)

To Cite this Article: Hata, H. A. M., Nor, M. Y. M., \& Hamid, A. H. A. (2020). The Influence of Distributed Leadership on Teachers' Competency in Secondary School. International Journal of Academic Research in Progressive Education and Development, 9(4), 53-66.

Copyright: (C) 2020 The Author(s)

Published by Human Resource Management Academic Research Society (www.hrmars.com)

This article is published under the Creative Commons Attribution (CC BY 4.0) license. Anyone may reproduce, distribute, translate and create derivative works of this article (for both commercial and non-commercial purposes), subject to full attribution to the original publication and authors. The full terms of this license may be seen at: http://creativecommons.org/licences/by/4.0/legalcode

\section{Vol. 9 (4) 2020, Pg. 53 - 66}

Full Terms \& Conditions of access and use can be found at http://hrmars.com/index.php/pages/detail/publication-ethics 


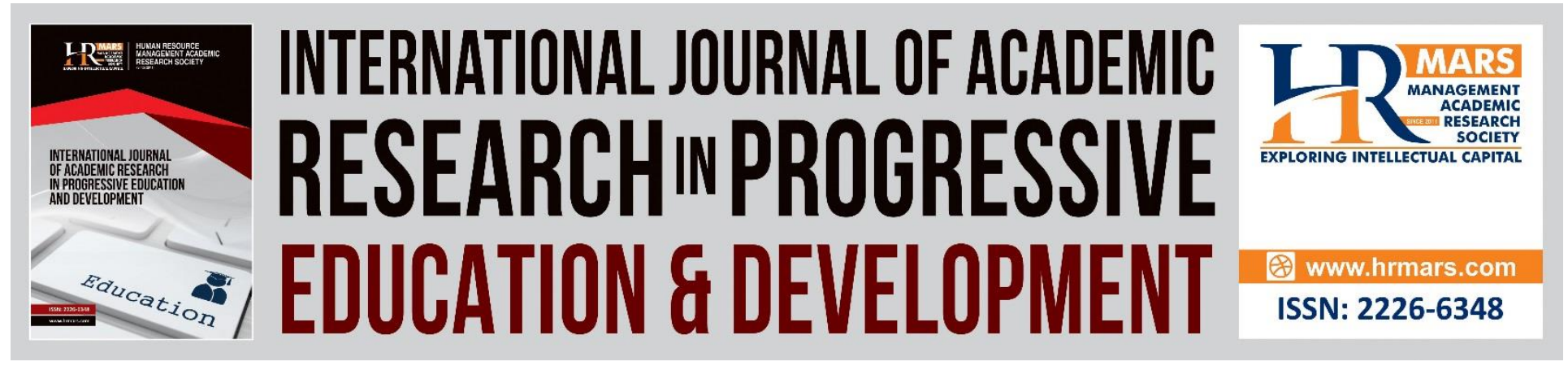

\title{
The Influence of Distributed Leadership on Teachers' Competency in Secondary School
}

\author{
Hairul Azman Mohd Hata, Mohamed Yusoff Mohd Nor, Aida \\ Hanim A. Hamid
}

Faculty of Education, National University of Malaysia

\begin{abstract}
School leadership plays an important role in achieving the desired goals and objectives of quality education. The leadership practices of principals are vital in effecting meaningful change and improvement in schools. In this study, the distributed leadership role of the principal is examined as a key strategic aspect that leads to teachers' competency. This is due to the main functions of distributed leadership that model the way, inspire a shared vision, challenge the process, enable others to act, and encourage the heart. Therefore, the main purpose of this study is to identify the level of distributed leadership practices of principals in secondary schools. Moreover, this study investigates the relationship between distributed leadership practices of school principals and teachers' competency. A quantitative research design was adopted to collect data, and a survey questionnaire was randomly distributed to 395 secondary school teachers. Data gathered from the respondents were analysed using SPSS (v.23) statistical software for both descriptive and inferential analyses. A descriptive analysis (mean and percentage) was used to identify the level of distributed leadership among principals and teachers' competency. Next, a Pearson linear correlation test was used to determine the relationships between five dimensions in the independent variable (distributed leadership) and dependent variable (teachers' competency). The research findings showed that the overall mean score for the level of distributed leadership of principals was moderately high (mean $=4.19 ; \mathrm{SD}=0.585$ ), and the overall mean score for the level of teachers' competency was also moderately high (mean $=4.39 ; \mathrm{SD}=0.430$ ). Additionally, there was a significant correlation between distributed leadership practices of principals and teachers' competency $(r=.496, p=0.05)$.
\end{abstract}

Keywords: Distributed Leadership, Principal, Competency, Teacher, Secondary School

\section{Introduction}

Principals are facing challenging times that demand they play an important role in managing their schools to produce outstanding students in not only academics and personality but also high accountability. To address today's leadership situation, scholars have used contemporary leadership concepts such as instructional, transformational, transactional, partnership, and distributed leadership as alternatives to traditional leadership concepts such as autocratic, laissez 
fair, and democratic leadership. In recent times, distributive leadership has gained scholars' attention because it helps principals deal with their increasing workload (Elmore, 2000; Spillane, 2006).

Distributed leadership is now recognised as one of the most successful approaches to school reform, and principals are encouraged to delegate their responsibilities to other school leaders. Although the term 'distributed leadership' is new and not well known, it has long been implemented as a part of education reforms in developed countries such as the United Kingdom, the United States, Australia, and New Zealand, as well as in parts of Europe (Harris, 2012). In the United States, principals are now assessed on their distributed leadership in accordance with new leadership standards (Council of Chief State School Officers, 2008). Similarly, the leadership preparation program considers how well a candidate is capable of exercising distributed leadership over delegated responsibilities (National Policy Board for Educational Administration, 2011).

The Ministry of Education Malaysia (MOE) has paid attention to distributed leadership through the Malaysian Education Development Plan (PPPM) 2013-2025 to strengthen leadership in schools. The fifth initiative of the PPPM 2013-2025 embodied the aspiration to place a highquality leader in each school.

Through its distributed leadership, MOE strives to address the increasing workload and stress principals face, especially regarding students' academic achievements. The MOE encourages other school leaders such as assistant principals, head teachers, and course leaders as well as teachers to be involved in school leadership, especially academic and teaching and learning decision-making processes, so that students' academic achievement can be improved (Ministry of Education, 2013).

Scholars recognise teachers' competency as a key component for school success. Through principals' distributed leadership, it is hoped that teachers' competency for achieving school development and student excellence can be enhanced.

\section{Statement of Problem}

The MOE recognises the importance and need to ensure that citizens have the identity and ability to contribute to the country's future. To realise this aspiration, the MOE has formulated a new policy of national education through the creation of the PPPM 2013-2025. The policy aims to produce students with six aspirations, namely, knowledge, thinking skills, leadership skills, bilingual skills, ethics and spirituality, and national identity, in line with Malaysia's national philosophy of education. To achieve this aim, the MOE strives to place a high-performing leader in every school (MOE, 2013). High-quality leaders must have a leadership style that is highly respected by all followers, especially teachers. Principals play an important role in driving schools towards success (Buckner, 2011; Leithwood \& Levin, 2010). A school is a complex organization that requires a manager who has capability and creativity as well as practices effective management strategies (Razak \& Abdullah, 2003). 
The variety of challenges in education today requires principals to adapt their leadership style to meet the current demands of education. Principals can no longer perform leadership as though they are putting on a 'one-man show'. They need to exercise shared responsibility and authority that engages certain activities and interactions based on a variety of people and situations (Camburn, Rowan, \& Taylor, 2004) Spillane, 2006). Therefore, principals need to explore distributed leadership options that encourage shared leadership and contribute to school improvement and student achievement (Chen, 2007). Further, through distributed leadership, teachers have the opportunity to enhance their capabilities and prepare for future leadership (MOE, 2013).

Having acknowledged the importance of establishing a successful school, the MOE now needs to focus on identifying and developing quality teacher talent to meet current educational demands (Lewis, 2015). Teachers need to be provided with the knowledge, skills, and positive values needed in current education to improve student achievement (Klenowski \& Lunt, 2008). Previous studies have found that a major factor influencing student achievement is teacher effectiveness, that is, the quality of a teacher (Clotfelter, Ladd, \& Vigor, 2011) To ensure that quality teachers are produced in every school, principals need to manage their teachers' talents by identifying them, providing training to enhance teachers' effectiveness, and improving student achievement (Odden, 2015).

Recognising the importance of leadership style in influencing teachers and the recognising need for principals to implement talent management to produce quality teachers, this examines the implementation of distributed leadership practices among principals in secondary schools. Additionally, this study analyses the relationship between distributed leadership and teachers' competency in secondary schools.

\section{Literature Review \\ Distributed Leadership}

The idea of distributed leadership has existed for the past few decades, but it only lately that scholars and policy makers around the world have begun to focus on it. Distributed leadership has long been practised in schools (Gronn, 2003), and it has gained increasing attention among scholars (Bolden, 2011; Hallinger \& Heck, 2010; Louis et al., 2010), who have used various terms to describe it. Distributed leadership is often seen as an analytical framework for understanding how leadership is implemented in schools or as an approach to improving school progress (Spillane, Halverson \& Diomond, 2001). It involves the distribution of tasks that involve leaders, followers, and situations and is a form of organisational leadership (Robinson, 2009).

From many different perspectives, various terms are used to describe the meaning of distributed leadership (Torrance, 2014). Harris et al. (2007) have suggested that distributed leadership refers to leadership-sharing activities. The terms most commonly used to describe this sharing activity are 'collaborative', 'collective', 'democratic', 'participatory', and 'instructional leadership sharing and distribution' (Klar et al., 2015). Hallinger and Heck (2009) used 'collaborative', 'shared', and 'distributed' to describe leadership practices by principals and assistant principals. 
Distributed leadership is also defined as a leadership phenomenon in which leadership tasks are not performed by an individual but are shared within an organisation (Storey, 2004; Yulk, 2002). Gibb used the term 'distributed leadership' in 1951 in the book Dynamics of Participative Groups, which stated that for the growth and development of organisational members, leaders needed to not only make maximum effort but also practise shared leadership. Richard Almore later expanded the term in the 1990 s to refer to delegating tasks and responsibilities to organisational members.

The distributed leadership style means transmitting power to subordinate leaders rather than the leadership moved among the members (Harris, 2003). This concept still places principals at the forefront of school planning and management (Lashway, 2003). One of the aspects of distributed leadership is to understand those involved in this process by identifying organisational members and examining how organisations operate and succeed in creating effective teams by maintaining a balance of expertise among members (Kamm \& Nurrick, 1993). Conger and Pearce (2003) argued that leadership is a dynamic process that involves interactive influences among organisational members aimed at achieving common goals. Shared leadership, collective leadership, and distributed leadership are viewed interchangeably, whereas team leadership is often seen as a slightly different research stream (Avolio, Walumbwa, \& Weber, 2009).

A number of studies by Harris (2008) showed that distributed leadership has been able to enhance positive motivation and work culture among teachers and school support staff. The leadership role given to teachers has helped to improve school achievement, especially that of students. Previous studies have also suggested that distributed leadership practices can improve school capacity, especially in regard to addressing changes in schools (Camburn, Rowan \& Taylor, 2003; Hallinger, 2011). Additionally, the actions of principals who encourage teachers in their work, such as thinking about the teaching and learning process, setting expectations about quality pedagogy, and supporting teachers' professional development enhance student learning in the classroom and thus affect students' achievement (Leitwood, Leonard \& Sharratt, 1988; Sevkusic et al., 2014)

However, there are some scholars who have expressed concerns about the implementation of distributed leadership in schools. Distributed leadership practices encourage the participation of many teachers as leaders, and this can lead to inefficiencies, conflicting priorities, competing leadership styles, poor culture, weak focus, and low productivity (Storey, 2004). Further, distributed leadership produces informal leaders, and this can cause employees to feel less valued and recognised (Harris, 2008). Therefore, principals, as the key leaders in schools, need to take appropriate steps to overcome the problems that may arise if distributed leadership practices are applied in schools.

In the current study, the concept of distributed leadership is defined based on Kouzes and Posner's (1995) theory of effective leadership, which five dimensions: setting an example, inspiring vision sharing, challenging processes, enabling others to act, and giving encouragement. 
Several studies on distributed leadership have been conducted in Malaysia. Among them is Wahab (2013) study, which analysed the relationship between the distributed leadership practices of headmasters and teachers' motivation in a national school in Port Klang. The study found that the level of distributed leadership among head teachers was high and that teachers' motivation was at a moderate level. Subsequent findings of the study showed a weak relationship $(r=0.28, p<0.005)$ between distributed leadership and teachers' motivation.

Another study related to distributed leadership examined the effect of distributed leadership on job stress in technical and vocational schools (Rabindarang, Bing, \& Yin, 2014) The study found that in technical and vocational schools distributed leadership was at a moderate level, as was the level of work pressure. Additionally, distributed leadership was found to reduce the work pressure of teachers in schools.

Halim \& Ahmad (2015) study found that principals' distributed leadership in secondary schools is at a moderate level and has a positive correlation with teacher effectiveness. Further, distributed leadership factors and contextual factors contribute $36 \%$ to the effectiveness of secondary school teachers. However, the study did not look at the relationship between distributed leadership and talent management.

\section{Teachers' Competency}

Teachers are the backbone of the education system. They are responsible for implementing all educational policies and curricula in schools. Having recognised the importance of teachers, the MOE has been focusing on developing new career pathways for teachers through the PPPM 2013-2025 in an effort to promote teaching as a profession of choice that is respected by the community.

Most scholars have found that teacher factors are often significantly associated with education quality as measured by student achievement. Koellner and Jacobs (2015); Yoon et.al. (2007); Wilson, Floden, and Ferrini-Mundy (2001); and Susilawati Husin (2008) stated that student performance is related to teacher professionalism because when teachers do not fulfil their responsibilities, students cannot learn well and achieve success. This clearly shows that teachers' competency is a key condition for successful teaching and learning processes. To ensure optimum competency, teachers should always strive for a better way while also contributing the best to others through professional development. At the same time, teachers play a key role in upholding their status and image as professionals (Sidin, 2002) To become competent teachers, they must focus on three important aspects: knowledge, personality development, and expertise (Sidin, 1998). Competent teachers are knowledgeable, skilled in teaching and learning processes, and can serve as role models to students (Sidin, 2002; Ibrahim et al., 2006). Further, teachers need to have in-depth knowledge in a field besides being experts in the education field (Tamuri \& Yusoff, 2011.

Various definitions and interpretations of competency have been given. Competency refers to the knowledge, skills, and personality traits necessary to perform a task or responsibility. 
According to the Kamus Dwibahasa Dewan, competence means competence, ability, willingness, and efficiency to perform a task (Dewan Bahasa dan Pustaka, 2004).

According to Daud Ibrahim (2003), competency means 'competence, proficiency, skillful and skill'. Competence is defined as the combination of aspects of knowledge, skills, and personal characteristics that must be acquired and practiced to perform a job. The basic principle of the competency model is that the performance of a public service officer will improve if he has all the competencies required to carry out the duties and responsibilities of his position. For example, specialization in a particular field and the frequency of performing a task will enable the officer to perform his or her tasks effectively. Agus Darma (2003) defines competency as the ability a person demonstrates when doing something.

\section{The Purpose of The Study}

The purpose of this study is to identify the distributed leadership practices of principals and the level of competency of teachers in secondary schools. Additionally, this study analyses the relationship between distributed leadership and teachers' competency. The dimensions of distributive leadership are modelling the way, inspiring a shared vision, challenging processes, allowing others to act, and giving encouragement. Aspects of teacher competency are teachers as planners, as supervisors, as encouragers, as mentors, and as evaluators.

\section{Research Methodology}

This was a quantitative study that used a cross-sectional survey design with a questionnaire as the research instrument. The survey design used in this study aimed to study the level of distributed leadership and teacher competency as well as analyse the relationship between distributed leadership and teacher competency in secondary schools based on questionnaires answered by respondents.

This study used a random sampling method, which involves a sample extraction process from any individual in the population that meets the criteria for study respondents. The sample in this study consisted of 395 teachers who were in secondary schools in Malaysia.

For the data analysis, this study used descriptive and inferential statistics. Descriptive statistics were applied to identify the distributed leadership practices of principals and teachers' competency level. Descriptive analysis based on the measurement of frequency, mean score, standard deviation, and percentage was conducted to obtain data in this study. Based on these descriptive statistics, the researcher could explain the mean and percentage frequency for all data contained in the questionnaire. Inferential analysis involving Pearson correlation analysis was used to obtain the correlation coefficient $(r)$ and examine the relationship between distributed leadership and teacher competency. 
INTERNATIONAL JOURNAL OF ACADEMIC RESEARCH IN PROGRESSIVE EDUCATION AND

DEVELOPMENT

Vol. 9, No. 4, 2020, E-ISSN: $2226-6348$ @ 2020 HRMARS

Table 1: Mean Score Interpretation

\begin{tabular}{lc}
\hline Scale Range & Mean Score Interpretation \\
\hline $1.00-1.50$ & Low \\
$1.51-2.49$ & Moderately Low \\
$2.50-3.49$ & Moderate \\
$3.50-4.49$ & Moderately High \\
$4.50-5.00$ & High \\
\hline
\end{tabular}

Source: Jamil Ahmad (2012)

\section{Findings}

\section{Respondents' Profile}

The study involves 395 respondents from secondary school teachers in Malaysia, which consist of 107 (27.10\%) male teachers and 288 (72.90\%) female teachers. Respondents of this study involved teachers from Fully Residential Schools (SBP) and National Secondary Schools (SMK). In terms of their education level, $3(0.80 \%)$ have a PhD, 52 (13.20\%) have a Master's Degree and $340(86.10 \%)$ teachers have a Bachelor degree. Whereas, in terms of teaching experience, 39 $(9.90 \%)$ teachers have less than 5 years teaching experience, $74(18.70 \%)$ teachers have been teaching for 6 - 10 year, 73 (18.50\%) teachers have been teaching for 11 - 15 years, 80 (20.30\%) have been teaching for 16 - 20 years and 129 (32.70\%) have been teaching for more than 20 years.

Table 2: Respondents' Profile

\begin{tabular}{cccc}
\hline Demography & Respondent & Frequency & Percentage \\
\hline Gender & Male & 107 & 27.10 \\
& Female & 288 & 72.90 \\
\hline Academic & PhD & 3 & 0.80 \\
& Master Degree & 52 & 13.20 \\
& Bachelor Degree & 340 & 86.10 \\
\hline Experience & Less than 5 years & 39 & 9.90 \\
& $6-10$ years & 74 & 18.70 \\
& $11-15$ years & 73 & 18.50 \\
& $16-20$ years & 80 & 20.30 \\
& More than 20 years & 129 & 32.70 \\
\hline
\end{tabular}

\section{Distributed Leadership of Principals}

According to Table 3, the overall distributed leadership level of the principals was at a moderately high level (Mean $=4.19 ; \mathrm{SD}=.585$ ). The highest dimension mean was for model the way at (Mean $=4.23$; $S D=.636$ ) and inspire a shared vision (Mean = 4.23; SD =.603), whereas the lowest mean was for enable others to act (Mean $=4.14$; SD $=.634$ ). The other dimensions were still at a moderately high level: encourage the heart (Mean $=4.20, S D=.697$ ) and challenge the process (Mean $=4.15, \mathrm{SD}=.607$ ). 
INTERNATIONAL JOURNAL OF ACADEMIC RESEARCH IN PROGRESSIVE EDUCATION AND DEVELOPMENT

Vol. 9, No. 4, 2020, E-ISSN: $2226-6348$ @ 2020 HRMARS

Table 3: Distributed Leadership Level of the Principals

\begin{tabular}{lccl}
\hline \multicolumn{1}{c}{ Dimension } & Mean Score & $\begin{array}{c}\text { Standard } \\
\text { Deviation }\end{array}$ & Interpretation \\
\hline Model the Way & 4.23 & .636 & Moderately High \\
Inspire a Shared Vision & 4.23 & .603 & Moderately High \\
Challenge the Process & 4.15 & .607 & Moderately High \\
Enable Others to Act & 4.14 & .634 & Moderately High \\
Encourage the Heart & 4.20 & .697 & Moderately High \\
Distributed Leadership & $\mathbf{4 . 1 9}$ &. $\mathbf{5 8 5}$ & Moderately High \\
\hline
\end{tabular}

\section{Teachers' Competency}

In Table 4 below, the overall teacher competency was found to be at a moderately high level (Mean $=4.39, \mathrm{SD}=.430$ ). In terms of teacher competency, teacher as a mentor had the highest mean score (Mean $=4.41$. SD $=.452$ ), whereas teacher as a planner had the lowest mean score (Mean $=4.34, \mathrm{SD}=.518)$; however, both were moderately high. Other aspects were also at a moderately high level: teachers as supervisors (Mean $=4.39, S D=.463$ ), teachers as encouragers (Mean $=4.39, \mathrm{SD}=.486$ ), and teachers as evaluators (Mean $=4.36, \mathrm{SD}=.467$ ).

Table 4: Teachers' Competencies

\begin{tabular}{lccc}
\hline \multicolumn{1}{c}{ Dimension } & $\begin{array}{c}\text { Mean } \\
\text { Score }\end{array}$ & $\begin{array}{c}\text { Standard } \\
\text { Deviation }\end{array}$ & Interpretation \\
\hline Teachers as Planners & 4.34 & .518 & Moderately High \\
Teachers as Supervisors & 4.39 & .463 & Moderately High \\
Teachers as Encouragers & 4.39 & .486 & Moderately High \\
Teachers as Mentors & 4.41 & .452 & Moderately High \\
Teachers as Evaluators & 4.36 & .467 & Moderately High \\
Teachers' Competencies & $\mathbf{4 . 3 9}$ & .430 & Moderately High \\
\hline
\end{tabular}

\section{Relationship Between Distributed Leadership and Teachers' Competency}

The third objective of the study was to analyse the relationship between distributed leadership and teachers' competency in secondary school. Table 5 shows that there was a significant positive relationship between distributed leadership and teachers' competency $(r=0.496 ; p=$ 0.005). Chua (2013) stated that a correlation coefficient of .00 means no correlation, .01 to .30 means very weak correlation, .31 to .50 means weak correlation, .51 to .70 means moderate correlation .71 to .90 means strong correlation, and .91 to 1.00 means very strong correlation. The relationship between distributed leadership and teachers' competency was thus weak. 
INTERNATIONAL JOURNAL OF ACADEMIC RESEARCH IN PROGRESSIVE EDUCATION AND DEVELOPMENT

Vol. 9, No. 4, 2020, E-ISSN: $2226-6348$ @ 2020 HRMARS

Table 5: Correlation between Distributed Leadership of Principals and

\begin{tabular}{llrr}
\multicolumn{3}{c}{ Teachers' Competency } \\
\hline & \multicolumn{2}{c}{ Distributed } & Competency \\
\hline Distributed & Pearson Correlation & 1 & $.496^{* *}$ \\
Leadership & Sig. (2-tailed) & .000 \\
Teachers' & Pearson Correlation & $.496^{* *}$ & 1 \\
Competency & Sig. (2-tailed) & .000 & \\
\hline
\end{tabular}

**. Correlation is significant at the 0.01 level (2-tailed).

\section{Discussion}

Based on the descriptive analysis, the distributed leadership of principals was at a moderately high level. The results of this study were in line with studies by previous researchers such as Rabindarang et al. (2015), Wahab et al. (2013), and Halim \& Ahmad (2015) which found that distributed leadership among principals and headmasters was at a moderately high level. Although the current study was carried out elsewhere and involved different samples, it produced very similar results to the previous studies.

In terms of teachers' competency, the study was at a moderately high level with a mean score of 4.44. This was in line with a study conducted by Radzi \& Muzammil (2018) on teachers at Sepang district that found that teachers' competency levels were moderate. Similarly, a study conducted by Hasan \& Mahamod (2016) on 226 secondary school teachers in Kuala Terengganu also found that teachers' competency levels were moderate.

The findings also showed that there was a significant positive relationship between distributed leadership and teachers' competency. This indicates that principals influence teachers' competency even when it is not very strong. All of a principal's behaviours affect the teachers in a school. This could be seen in the distributed leadership dimensions, with the modelling the way dimension having the highest mean score (4.29). Principals thus set a good example for teachers in performing school tasks. Teachers see principals as role models; this is consistent with the roles and responsibilities of school principals.

\section{Conclusion}

Overall, the findings showed that the level of distributed leadership of principals based on the dimensions of modelling the way, inspiring a shared vision, challenging the process, allowing others to act, and giving encouragement is moderately high. Likewise, the level of competency of teachers in the aspects of teachers as planners, supervisors, encouragers, mentors, and evaluators is moderately high. Additionally, the findings showed that there is a significant positive relationship (strong correlation) between distributed leadership and talent management by principals.

This is in line with the MOE's aspiration to ensure, through the PPPM 2013-2025, that highperforming principals and teachers are placed in schools. Further, the findings of this study 
provide additional incentive to the MOE to pay attention to the distributed leadership and talent management of school principals to ensure that Malaysia's Ministry of Higher Education achieves its goals and objectives. Because this is a quantitative study, researchers recommend conducting qualitative studies in the future to determine how principals practise distributed leadership in schools so that teachers' competencies are always at an optimum level. Additionally, further studies need to be conducted in other states or across Malaysia for a more comprehensive and more accurate generalisation.

\section{Contribution of Study}

This study emphasizes the importance of professional improvement of principals and teachers to create an effective delivery system and conducive leaning. In addition, this study is expected to provide information related to the importance and need to manage talent management effectively and efficiently to provide talented groups of teacher leadership in school for purpose of effective principal succession planning. This study also significantly to the education system in Malaysia, especially in the field of leadership. This study successfully proves the importance of distributed leadership to produce teachers who have high competencies in schools.

\section{Acknowledgement}

I would like to express my deepest gratitude to my supervisors, Dr. Mohamed Yusoff Mohd Nor and Dr. Aida Hanim A.Hamid for their continuous guidance in the preparation of this paper.

\section{Corresponding Author}

Hairul Azman Mohd Hata

Ph.D candidate Faculty of Education, National University of Malaysia

Email: hairul.jnjk@gmail.com

\section{References}

Avolio, B. J., Walumbwa, F. O., \& Weber, T. J. (2009). Leadership: Current theories, research, and future directions. Annual Review of Psychology, 60, 421-449.

Bolden, R. (2011). Distributed leadership in organizations: A review of theory and research. International Journal of Management Reviews, 13, 251-269

Buckner, K. R. (2011). Leadership practices of female principals (PhD dissertation) Capella University. US

Camburn, E., Rowan, B., \& Taylor, J. E. (2003). Distributed leadership in schools: The case of elementary schools adopting comprehensive school reform models. Educational Evaluation and Policy Analysis, 25, 347-373.

Chen, Y. (2007). Principals' distributed leadership behaviors and their impact on student achievement in selected elementary schools In Texas (PhD dissertation), Texas A\&M University

Clotfelter, C. T., Ladd, H. F., \& Vigdor, J. L. (2011). Teacher mobility, school segregation, and pay-based policies to level the playing field. Education Finance and Policy, 6(3), 399-438

Conger, J. A., \& Pearce, C. L. (2003). Shared leadership: Reframing the hows and whys of Leadership. Thousand Oaks, CA: Sage 
INTERNATIONAL JOURNAL OF ACADEMIC RESEARCH IN PROGRESSIVE EDUCATION AND

DEVELOPMENT

Vol. 9, No. 4, 2020, E-ISSN: $2226-6348 @ 2020$ HRMARS

Council of Chief State School Officers. (2008). Educational leadership policy standards: SLLC 2008. Washington, DC:

Elmore, R. (2000). Building a new structure for school leadership. Washington, DC: The Albert Shanker Institute

Gronn, P. (2003) The new work of educational leaders:Changing leadership practice in an era of school reform. London:Paul Chapman.

Halim, R. A., \& Ahmad, H. (2015). Kepemimpinan distributif, faktor kontekstual dan efikasi kendiri guru di Malaysia. Jurnal Pendidikan Bil. 2(4):47-61

Hallinger, P., \& Heck, R. H. (2009). Distributed leadership in schools: Does system policy make a difference? In A. Harris (Ed.), Distributed leadership: Studies in educational leadership (pp. 101-117). New York, NY: Springer.

Harris, A. (2012). Distributed leadership: Implications for the role of the principal. Journal of Management Development, 31, 7-17

Harris, A., Leithwood, K., Day, C., Sammons, P., \& Hopkins, D. (2007). Distributed leadership and organizational change: Reviewing the evidence. Journal of Educational Change, 8, 337347.

Harris, A. (2008). Distributed Leadership in Shools: Developing the Leaders of Tomorrow. Routledge \& Falmer Press

Hasan, N. H., \& Mahamod, Z. (2016). Persepsi guru bahasa Melayu sekolah menengah terhadap kemahiran berfikir aras tinggi. Jurnal Pendidikan Bahasa Melayu, 6(2), 78-90.

Ibrahim, M. S., Mahamod, Z., \& Othman, N. (2006). Kesediaan profesionalisme guru novis: Cadangan model latihan (1-10). Bangi: Universiti Kebangsaan Malaysia.

Kamm, J. B., \& Nurick, A. J. (1993). The Stages of Team Venture Formation: A Decision-making Model. Entrepreneurship: Theory \& Practice, 17(2), 17-27.

Koellner, K., \& Jacobs, J. (2015). Distinguishing Models of Professional Development: The Case of an adaptive model's impact on teachers' knowledge, instruction, and student achievement. Journal of Teacher Education, 66 (1), 51-67.

Kouzes J., \& Posner B. (1995). The Leadership Challenge. Second Eition. San Francisco, JosseyBass.

Lashway, L. (2003). Role of the school leader: Trends and issues. Washington, DC: Office of Educational Research and Improvement. (ERIC Document Reproduction Service No. ED479933)

Leithwood, K., \& Levin, B. (2010). Understanding how leadership influences student learning. Oxford, UK: Elsevier.

Leithwood, K., Leonard, L., and Sharratt, L. (1988). Conditions fostering organizational learning in schools. Educational Administration Quarterly 34(2): 243-276

Lewis, M. O. (2015). An integrated approach to teaching the capstone strategic management course: A left- and right-brained approach. Business Education Innovation Journal, 3(2), 66-72.

Louis, K. S., Leithwood, K., Wahlstrom, K. L., \& Anderson, S. E. (2010). Learning from leadership: Investigating the links to improved student learning. Minneapolis, MN: Center for Applied Research and Educational Improvement, University of Minnesota. 
INTERNATIONAL JOURNAL OF ACADEMIC RESEARCH IN PROGRESSIVE EDUCATION AND

DEVELOPMENT

Vol. 9, No. 4, 2020, E-ISSN: $2226-6348$ @ 2020 HRMARS

Man, J., Don, Y., \& Ismail, S. N. (2016). Transformational leadership and teachers' quality among teachers of generation ' $Y$ '. Jurnal Kepimpinan Pendidikan, Bil. 3(1): 29-42

National Policy Board for Educational Administration. (2011). Educational leadership program recognition standards: Building level. Arlington, VA

Odden, A. R. (2015). Strategic management of human capital in education. New York, NY: Routledge

Rabindarang, S., Bing, K. W., \& Yin, K. Y. (2014). The influence of distributed leadership on job stress in technical and vocational education. International Journal of Academic Research in Business and Social Sciences, 4(1):490-499

Radzi, N. M., \& Muzammil, N. F. (2018). Tahap kompetensi guru dalam pelaksanaan kemahiran berfikir aras tinggi di Sekolah Kebangsaan daerah Sepang, Selangor. Jurnal Kurikulum \& Pengajaran Asia Pasifik, 6(4):12-28

Raman, A., Mey, C. H., Don, Y., Daud, Y., \& Khalid, R. (2015). Relationship between principal's transformation leadership style and secondary school teachers' commitment. Asian Social Science, 11(15), 221-228.

Razak, N. A., \& Abdullah, W. M. R. (2003). Amalan bidang pengetua dari perspektif guru. Digest Pendidik, 3(1), 23-35.

Robinson, V. M. J. (2009). Fit for purpose: An educationally relevant account of distributed leadership. New York, NY: Springer.

Sevkusic, S., Andelkovic, S., and Milin, V. (2014). Classroom climate in Serbia: The perspective of primary school teachers. Ministry of Education, Science and Technological Development of the Republic of Serbia. 277-298

Sidin, R. (1998). Pemikiran dalam pendidikan. Shah Alam: Fajar Bakti.

Sidin, R. (2002). Konsep guru profesional. Prosiding Seminar Kebangsaan Profesion Perguruan 2002. Profesion Perguruan: Cabaran Masa Kini (1-11). Bangi: Universiti Kebangsaan Malaysia.

Spillane, J. P. (2006). Distributed Leadership. San Francisco, CA: Jossey-Bass.

Spillane, J. P., Halverson, R., \& Diamond, J. B. (2001). Investigating school leadership practice: A distributed perspective. Educational Researcher, 30, 23-28.

Storey, A. (2004). The problem of distributed leadership in school. School Leadership and Management

Husin, S. (2008). Hubungan antara profesionalisme guru dan prestasi pendidikan agama Islam di kalangan pelajar Madrasah Aliyah Negeri (MAN), Tanjung Pinang, Indonesia. Tesis Sarjana Pendidikan tidak diterbitkan. Universiti Kebangsaan Malaysia, Bangi.

Tamuri, A. H., \& Yusoff, N. M. R. N. (2011). Isu pengajaran dan pembelajaran pendidikan Islam. dalam Ab. Halim Tamuri \& Nik Mohd. Rahimi Nik Yusoff (pnyt), Kaedah pengajaran dan pembelajaran pendidikan Islam (19-37). Bangi: Penerbit UKM.

Torrance, D. (2014). Distributed leadership: Challenging five generally held assumptions. School Leadership and Management, 33, 354-372.

Wahab, J. A., Hamid, A. H. A., Zainal, S., \& Rafik, M. F. M. (2013). The relationship between headteachers' distributed leadership practices and teachers' motivation in national primary schools. Asian Social Science, 9(16): 161-167 
INTERNATIONAL JOURNAL OF ACADEMIC RESEARCH IN PROGRESSIVE EDUCATION AND

DEVELOPMENT

Vol. 9, No. 4, 2020, E-ISSN: 2226-6348 @ 2020 HRMARS

Wilson, S. M., Floden, R. E., \& Ferrini-Mundy, J. (2001). Teacher preparation research: current knowledge, gaps, and recommendations. Seattle, WA: Center for the Study of Teaching and Policy.

Yoon, K. S., Duncan, T., Lee, S. W-Y., Scarloss, B., \& Shapley, K. L. (2007). Reviewing the evidence on how teacher professional development affects student achievement. Washington, D.C: Institute of Education Sciences.

Yukl, G. A. (2002). Leadership in organizations. Fifth edition, upper Saddle River, NJ, Prentice Hall. 